\title{
Effects of different $\mathbf{N}$ sources on riverine DIN export and retention in a subtropical high-standing island, Taiwan
}

\author{
Jr-Chuan Huang ${ }^{1}$, Tsung-Yu Lee ${ }^{2}$, Teng-Chiu Lin ${ }^{3}$, Thomas Hein ${ }^{4,8}$, Li-Chin Lee ${ }^{1}$, Yu-Ting Shih ${ }^{1}$, Shuh-Ji Kao ${ }^{5}$, \\ Fuh-Kwo Shiah ${ }^{6}$, and Neng-Huei Lin $^{7}$ \\ ${ }^{1}$ Department of Geography, National Taiwan University, Taipei, Taiwan \\ ${ }^{2}$ Department of Geography, National Taiwan Normal University, Taipei, Taiwan \\ ${ }^{3}$ Department of Life Science, National Taiwan Normal University, Taipei, Taiwan \\ ${ }^{4}$ Institute of Hydrobiology and Aquatic Ecosystem Management, University of Natural Resources \\ and Life Sciences, Vienna, Austria \\ ${ }^{5}$ State Key Laboratory of Marine Environmental Science, Xiamen University, Xiamen, China \\ ${ }^{6}$ Research Centre of Environmental Changes, Academia Sinica, Taipei, Taiwan \\ ${ }^{7}$ Department of Atmospheric Sciences, National Central University, Taoyuan, Taiwan \\ ${ }^{8}$ WasserCluster Lunz, Dr. Kupelwieser-Prom. 5, 3293 Lunz am See, Austria \\ Correspondence to: Teng-Chiu Lin (tclin@ntnu.edu.tw)
}

Received: 14 September 2015 - Published in Biogeosciences Discuss.: 7 October 2015

Revised: 3 February 2016 - Accepted: 4 March 2016 - Published: 23 March 2016

\begin{abstract}
Increases in nitrogen $(\mathrm{N})$ availability and mobility resulting from anthropogenic activities have substantially altered the $\mathrm{N}$ cycle, both locally and globally. Taiwan characterized by the subtropical montane landscape with abundant rainfall, downwind of the most rapidly industrializing eastern coast of China, can be a demonstration site for extremely high $\mathrm{N}$ input and riverine DIN (dissolved inorganic N) export. We used 49 watersheds with similar climatic and landscape settings but classified into low, moderate, and highly disturbed categories based on population density to illustrate their differences in nitrogen inputs (through atmospheric $\mathrm{N}$ deposition, synthetic fertilizers, and human emission) and DIN export ratios. Our results showed that the island-wide average riverine DIN export is $\sim 3800 \mathrm{~kg} \mathrm{~N} \mathrm{~km}^{-2} \mathrm{yr}^{-1}$, approximately 18 times the global average. The average riverine DIN export ratios are 0.30 0.51 , which are much higher than the averages of $0.20-0.25$ of large rivers around the world, indicating excessive $\mathrm{N}$ input relative to ecosystem demand or retention capacity. The low disturbed watersheds have a high $\mathrm{N}$ retention capacity and DIN export ratios of $0.06-0.18$ in spite of the high $\mathrm{N}$ input $\left(\sim 4900 \mathrm{~kg} \mathrm{~N} \mathrm{~km}^{-2} \mathrm{yr}^{-1}\right)$. The high retention capacity is likely due to effective uptake by secondary forests in the watersheds. The moderately disturbed watersheds show a lin-
\end{abstract}

ear increase in DIN export with increases in total $\mathrm{N}$ inputs and mean DIN export ratios of 0.20 to 0.31 . The main difference in land use between low and moderately disturbed watersheds is the greater proportion of agricultural land cover in the moderately disturbed watersheds. Thus, their greater DIN export could be attributed to $\mathrm{N}$ fertilizers used in the agricultural lands. The greater export ratios also imply that agricultural lands have a lower proportional $\mathrm{N}$ retention capacity and that reforestation could be an effective land management practice to reduce riverine DIN export. The export ratios of the highly disturbed watersheds are very high, 0.42-0.53, suggesting that much of the $\mathrm{N}$ input is transported downstream directly, and urges the need to increase the proportion of households connected to a sewage system and improve the effectiveness of wastewater treatment systems. The increases in the riverine DIN export ratio along the gradient of human disturbance also suggest a gradient in $\mathrm{N}$ saturation in subtropical Taiwan. Our results help to improve our understanding of factors controlling riverine DIN export and provide empirical evidence that calls for sound $\mathrm{N}$ emission/pollution control measures. 


\section{Introduction}

Rapid increases in population and food demand inevitably hasten the emissions of anthropogenic nitrogen $(\mathrm{N})$ via $\mathrm{N}$ rich sewage, fertilizer runoff, and burning of fossil fuels, and have led to a 10 -fold increase in anthropogenic $\mathrm{N}$ emissions since the 1860s (Galloway et al., 2004). The elevated anthropogenic $\mathrm{N}$ emissions have increased the availability and mobility of $\mathrm{N}$ and as such altered the $\mathrm{N}$ cycle (Vitousek et al., 1997; Gruber and Galloway, 2008). A substantial proportion of the increased $\mathrm{N}$ input is transported to river systems. In riverine systems, $\mathrm{N}$ species can be classified into PN (particulate nitrogen), DON (dissolved organic nitrogen), and DIN (dissolved inorganic nitrogen, including $\mathrm{NO}_{2}, \mathrm{NO}_{3}$, and $\mathrm{NH}_{4}$ ), among which DIN is an important indicator of water quality and comprises the majority of total riverine $\mathrm{N}$ in most rivers (Galloway et al., 2004; McCrackin et al., 2014). Observed global riverine DIN export varies from 0.60 to $2200 \mathrm{~kg} \mathrm{~N} \mathrm{~km}^{-2} \mathrm{yr}^{-1}$ (He et al., 2011), while modeled DIN export varies from 0.0004 to $5217 \mathrm{~kg} \mathrm{~N} \mathrm{~km}^{-2} \mathrm{yr}^{-1}$ (Dumont et al., 2005). The more than 6-order variation reflects the large spatial variation and complexity of $\mathrm{N}$ input, retention, and transport processes (Howarth, 1998; Smith et al., 2005; Seitzinger et al., 2005). The recent high $\mathrm{N}$ input may have exceeded the limit of the earth system as a safe operating space for humanity (Rockström et al., 2009). Unfortunately, the increasing trend of $\mathrm{N}$ emissions is likely to continue in the near future, especially in Asia (Ohara et al., 2007). A high quantity of $\mathrm{N}$ fertilizers has been shown to degrade soil fertility and water quality, and creates hypoxic zones in coastal areas (Fitzpatrick et al., 2004; Brown et al., 2009; Tu, 2009). Because $\mathrm{N}$ is a common limiting nutrient element in many ecosystems, availability of $\mathrm{N}$ plays a key role in characterizing biodiversity and ecosystem function (Aber, 1989; Aber et al., 1998). Anthropogenic $\mathrm{N}$ enrichment has been shown to negatively affect ecosystem function and biodiversity at a global scale (Townsend et al., 2009; Hutchison and Henry, 2010).

In freshwater systems, eutrophication is a common consequence of increases in DIN availability, aside from increases in phosphorus levels (Conley et al., 2009). To date, most empirical studies of DIN export have been conducted at a geographically limited group of drainage basins in the developed temperate region (Smith et al., 2005; Galloway et al., 2008). In contrast, $\mathrm{N}$ deposition and DIN export in subtropical and tropical regions such as East Asia, characterized by high population, an intensive agriculture system, and rapid industrialization, are not well documented. Because industrialization in East Asia is among the most rapid in the world, the impact of enhanced anthropogenic $\mathrm{N}$ emissions on watershed nutrient cycling is expected to get worse in the near future. Understanding DIN concentration and export in this region is crucial for a thorough understanding of global nutrient cycling in relation to anthropogenic $\mathrm{N}$ emissions.
Increases in population, agriculture activities, and atmospheric $\mathrm{N}$ deposition are well-recognized sources of elevated riverine DIN export. $\mathrm{N}$ retention and transfer processes determine how much of the $\mathrm{N}$ entering a watershed will be exported to the river system as DIN. In most riverine systems, DIN export is typically less than the total $\mathrm{N}$ input, and the riverine DIN export ratio, defined as the DIN export divided by the total input, can be used to evaluate the nutrientcycling function of a watershed. Quantification of $\mathrm{N}$ inputs and outputs of river systems with different levels of human disturbance (e.g., Groffman et al., 2004) document how human activities affect $\mathrm{N}$ cycling at scales that are relevant to land management. Previous studies indicated that $\sim 20-25 \%$ of the $\mathrm{N}$ input is transported by river systems, and the rest is retained or denitrified in large river basins in North America and Europe (Howarth et al., 2006). Furthermore, it has been proposed that riverine $\mathrm{N}$ export from the large rivers will increase $10-27 \%$ in the next 3 decades due to the increase in $\mathrm{N}$ input, while the riverine $\mathrm{N}$ export ratio may increase 10 $35 \%$ due to increases in rainfall that may shorten the water residence time (Howarth et al., 2006). Compared to the temperate region, we have very limited knowledge on riverine $\mathrm{N}$ export ratios in relation to human activities in tropical and subtropical regions regardless of their very rapid increases in $\mathrm{N}$ emissions.

Taiwan is a $36000 \mathrm{~km}^{2}$ subtropical island characterized by rugged topography, high rainfall, high industrialization and a very large population ( 23 million). Like many countries in East Asia the emissions of $\mathrm{N}$ and export of DIN in Taiwan is expected to be very high. In addition, the rich background information on various $\mathrm{N}$ inputs, topography and land use intensity make Taiwan an ideal site to assess the relative contributions of major emission sources to total $\mathrm{N}$ input and the effects of physical environmental characteristics and human impacts on DIN export. Therefore, this study aims to (1) characterize riverine DIN export in subtropical watersheds in Taiwan and (2) explore the relationship between land use and DIN export in Taiwanese rivers and compare it to riverine systems in other parts of the world.

\section{Methods}

\subsection{Population density and land use}

There are approximately 23 million people living in the $36000 \mathrm{~km}^{2}$ Taiwan, giving a population density of $\sim 640 \mathrm{cap} \mathrm{km}^{-2}$ (Fig. 1a). Most people live in the western plains, particularly in cities. For example, approximately 6.7 million people live in the Taipei metropolitan area, and the population density reaches $20000 \mathrm{cap} \mathrm{km}^{-2}$. There are a total of 49 wastewater treatment centers (most of them located in the cities) with a daily capacity of $\sim 2.3$ million ton of water in Taiwan (http://sewagework.cpami.gov.tw/). Most of them are equipped with secondary treatments that remove $80 \%$ of $\mathrm{NH}_{4}$. Yet, $\mathrm{NO}_{3}$ removal is not required, so that the 

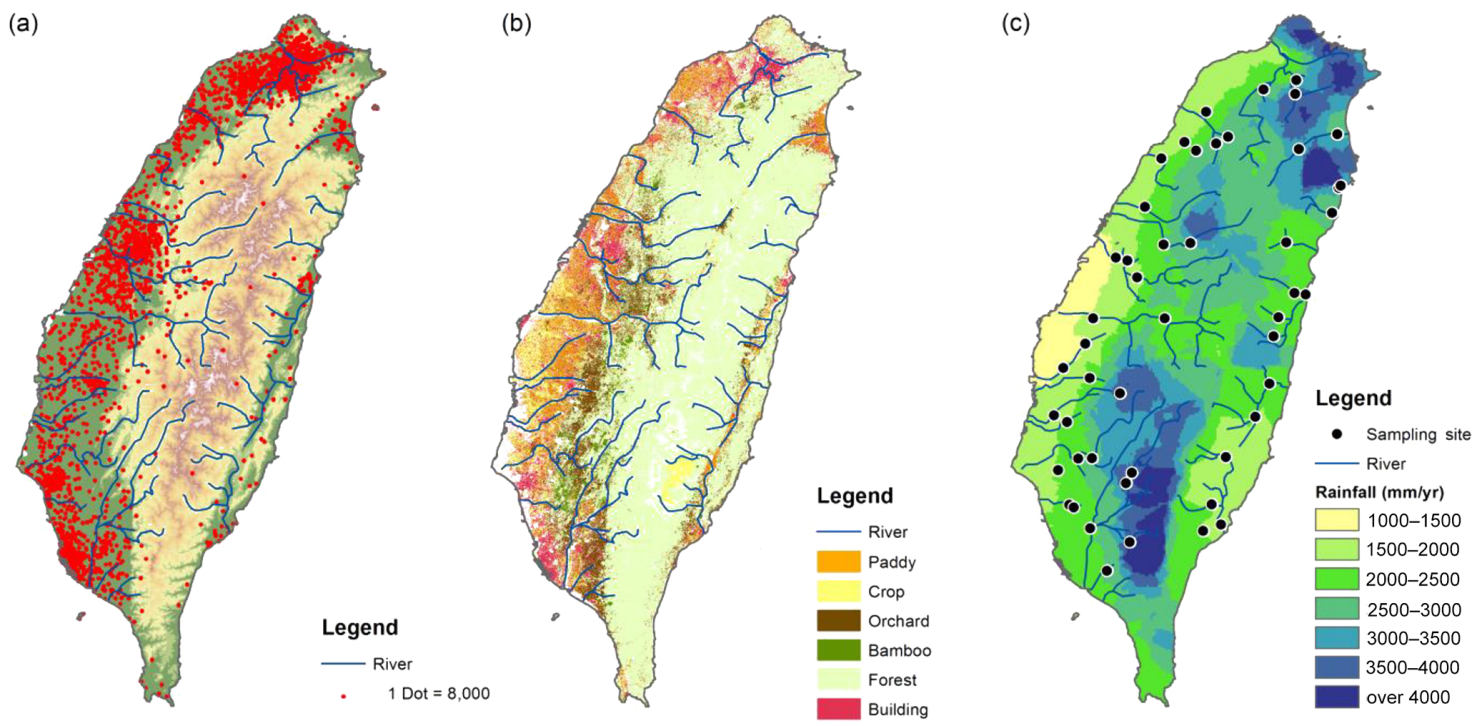

Figure 1. Three maps of Taiwan to show the population density (a), land cover (b), and mean annual rainfall (c). The annual rainfall data set is provided by the water resources agency for 2002-2012. The population data set is derived from a county census from the Ministry of the Interior. The land cover data set was distributed by the Ministry of the Interior in 2006.

average $\mathrm{N}$ removal efficiency is only $\sim 50 \%$. As of 2003 , approximately 70 and $30 \%$ of the households in Taipei and Kaohsiung (the two largest cities in Taiwan) had been connected to a sewage system, respectively. The distribution of the water treatment centers and their treatment capacity are given in Fig. S1 in the Supplement.

Forests cover approximately $58 \%$ of Taiwan (mostly in the mountains) and agricultural lands are mainly distributed on the western plains, with some scattered on the hillsides. The agriculture in Taiwan is characterized by an intensive cropping system with two to five harvests a year (two batches per year for paddy rice) due to intense sunlight, high precipitation and high temperature. The total arable land area is $\sim 8550 \mathrm{~km}^{2}$, in which paddy fields account for $4445 \mathrm{~km}^{2}$ mostly on the western plain (Fig. 1b). Fodder and sweet maize are planted on the plains from central to southern Taiwan and sugar canes are cultivated in the southern coastal plain (COA, Council of agriculture, executive yuan, Taiwan, http://www.coa.gov.tw). Most of the remaining arable lands $\left(4100 \mathrm{~km}^{2}\right)$ spread over the hills, usually along roadsides or stream sides, with some distributed in uplands with tea, orchards, vegetables, and bamboo as the main crops. The field area of tea is approximately $190 \mathrm{~km}^{2}$ and of bamboo is approximately $300 \mathrm{~km}^{2}$. Agriculture production in Taiwan largely depends on very high applications of synthetic fertilizers and crop protection measures. According to the COA survey, $500 \mathrm{~kg} \mathrm{~N} \mathrm{ha}^{-1}$ of $\mathrm{N}$ fertilizers are commonly applied for bamboo fields, $420 \mathrm{~kg} \mathrm{Nha}^{-1}$ for tea plantations, and $246 \mathrm{~kg} \mathrm{Nha}^{-1}$ for rice paddy annually (Table 1). For other crops, such as maize, sugar cane, watermelon, banana, and pineapple, more than $100 \mathrm{~kg} \mathrm{Nha}^{-1}$ of $\mathrm{N}$ fertilizers per year are applied (Table 1). The intensive fertilizer applications are not unique to Taiwan, as they are also common in other countries of East Asia. For example, synthetic fertilizers applied in Lake Dianchi in China are as high as $150-200 \mathrm{~kg} \mathrm{Nha}^{-1}$ annually (Gao et al., 2014).

\subsection{Basic watershed characteristics}

A total of 49 watersheds distributed throughout the island are used for estimating watershed DIN export in this study (Fig. 1c). The watersheds are classified into three levels of human disturbance, low disturbed (16 watersheds), moderately disturbed (15 watersheds), and highly disturbed (18 watersheds), based on population densities of $<20,20-200$, and $>200 \mathrm{cap} \mathrm{km}^{-2}$. The environmental settings of the three categories of watersheds are given in Table 2. Most of the watersheds have drainage areas of less than $1000 \mathrm{~km}^{2}$. The average slopes and drainage densities of the three categories of watersheds vary from 66 to $29 \%$ and from 1.4 to $1.6 \mathrm{~km}^{-1}$ (Table 2). The mean annual runoff of the 49 watersheds varies from 2200 to $2500 \mathrm{~mm}$ and the mean annual precipitation varies from 2000 to $4000 \mathrm{~mm}$.

Forests dominate the landscape of all of the 49 watersheds, and the proportion of forest cover decreases from 0.87 for low disturbed watersheds to 0.51 for highly disturbed watersheds (Table 3 ). In contrast, the proportion of built-up lands increases from 0.03 for low disturbed watersheds to 0.11 for highly disturbed watersheds, and the proportion of agricultural lands increases from 0.11 for low disturbed watersheds to 0.38 for highly disturbed watersheds (Table 3 ). While non-rice crops and orchards dominate the agricultural lands in all of the three categories of watersheds (> 80\%), rice paddy and bamboo are important only in highly disturbed 
Table 1. Crop area and yield and estimated quantities of fertilizers used in Taiwan (from FAO, 2002) ${ }^{\mathrm{a}}$.

\begin{tabular}{lrrrrr}
\hline Crop & $\begin{array}{r}\text { Harvested } \\
\text { area (ha) }\end{array}$ & $\begin{array}{r}\text { Average yield } \\
\left(\mathrm{kg} \mathrm{ha}^{-1}\right)\end{array}$ & \multicolumn{3}{c}{$\begin{array}{r}\text { Est. quantities of fertilizers } \\
\text { used }^{\mathrm{b}} \text { (ton) }\end{array}$} \\
\cline { 3 - 6 } & & & $\mathrm{N}$ & $\mathrm{P}_{2} \mathrm{O}_{5}$ & $\mathrm{~K}_{2} \mathrm{O}$ \\
\hline Paddy and rice & 353065 & 10646 & 41793 & 15314 & 16462 \\
Maize (fodder and sweet) & 34854 & 11970 & 3485 & 2440 & 1742 \\
Groundnut & 26495 & 2535 & 539 & 1192 & 1060 \\
Sugar cane & 30657 & 81337 & 6438 & 1073 & 2146 \\
Tea & 19142 & 1103 & 8040 & 2680 & 2680 \\
Bamboo shoot & 29819 & 12030 & 14910 & 3727 & 5069 \\
Watermelon & 19720 & 19685 & 3550 & 2366 & 3944 \\
Banana & 8961 & 23718 & 2216 & 1090 & 4433 \\
Pineapple & 7340 & 47474 & 2422 & 440 & 1321 \\
Mango & 18700 & 11065 & 449 & 299 & 673 \\
Litchi & 10530 & 9385 & 316 & 211 & 284 \\
\hline
\end{tabular}

${ }^{a}$ Only the primary crops are listed. ${ }^{b}$ The fertilizer amounts are suggested by the COA (Council of Agriculture,

Taiwan), which surveys the crop plantation and declares the suggested values for farmers.

Table 2. Watershed environmental settings of the three categories of watersheds.

\begin{tabular}{lc|cccccc}
\hline Category & Number & $\begin{array}{c}\mathrm{N} \mathrm{deposition}_{\left(\mathrm{kg} \mathrm{N} \mathrm{km}^{-2}\right)} \\
\left(\mathrm{km}^{2}\right)\end{array}$ & $\begin{array}{c}\text { Area } \\
(\mathrm{mm})\end{array}$ & $\begin{array}{c}\text { Rug. slope } \\
(\%)\end{array}$ & $\begin{array}{c}\mathrm{DD}^{\mathrm{a}} \\
\left(\mathrm{km}^{-1}\right)\end{array}$ & $\begin{array}{c}\text { Pop. den. } \\
\left(\mathrm{cap} \mathrm{km}^{-2}\right)\end{array}$ \\
\hline Low & 16 & 2224 & 592 & 2250 & 66.3 & 1.35 & 11.4 \\
disturbed & $(369)$ & $(486)$ & $(554)$ & $(5.6)$ & $(0.05)$ & $(4.2)$ & \\
\hline Moderately & 15 & 2030 & 1030 & 2420 & 55.3 & 1.40 & 55.2 \\
disturbed & $(458)$ & $(913)$ & $(638)$ & $(7.6)$ & $(0.10)$ & $(22.2)$ & \\
\hline Highly & 18 & 2200 & 379 & 2270 & 29.1 & 1.63 & 598 \\
disturbed & $(352)$ & $(462)$ & $(542)$ & $(14.0)$ & $(0.18)$ & $(586)$ & \\
\hline
\end{tabular}

a DD: drainage density defined as the total stream length over drainage area; the unit is $\left(\mathrm{km}^{-1}\right)$.

The values and the parentheses indicate the means and the standard deviations of the individual category.

Table 3. Relative land cover composition of the three categories of watersheds.

\begin{tabular}{l|ccccccc}
\hline \multirow{2}{*}{ Category } & Forest & Built-up & \multicolumn{5}{c}{ Agriculture } \\
\cline { 3 - 8 } & & & Total & Paddy & Crops & Orchard & Bamboo \\
\hline $\begin{array}{l}\text { Low } \\
\text { disturbed }\end{array}$ & $\begin{array}{c}0.87 \\
(0.06)\end{array}$ & $\begin{array}{c}0.03 \\
(0.01)\end{array}$ & $\begin{array}{c}0.11 \\
(0.08)\end{array}$ & $\begin{array}{c}0.0 \\
\text { N/A }\end{array}$ & $\begin{array}{c}0.05 \\
(0.06)\end{array}$ & $\begin{array}{c}0.05 \\
(0.03)\end{array}$ & $\begin{array}{c}0.01 \\
(0.01)\end{array}$ \\
\hline $\begin{array}{l}\text { Moderately } \\
\text { disturbed }\end{array}$ & $\begin{array}{c}0.81 \\
(0.11)\end{array}$ & $\begin{array}{c}0.03 \\
(0.01)\end{array}$ & $\begin{array}{c}0.16 \\
(0.10)\end{array}$ & $\begin{array}{c}0.02 \\
(0.03)\end{array}$ & $\begin{array}{c}0.05 \\
(0.06)\end{array}$ & $\begin{array}{c}0.08 \\
(0.08)\end{array}$ & 0.02 \\
\hline $\begin{array}{l}\text { Highly } \\
\text { disturbed }\end{array}$ & $\begin{array}{c}0.51 \\
(0.22)\end{array}$ & $\begin{array}{c}0.11 \\
(0.05)\end{array}$ & $\begin{array}{c}0.38 \\
(0.19)\end{array}$ & $\begin{array}{c}0.06 \\
(0.08)\end{array}$ & $\begin{array}{c}0.09 \\
(0.06)\end{array}$ & $\begin{array}{c}0.23 \\
(0.13)\end{array}$ & $\begin{array}{c}0.08 \\
(0.11)\end{array}$ \\
\hline
\end{tabular}

Parentheses indicate the standard deviation of the individual category.

N/A: no paddy in the low disturbed watersheds.

Note that the national land use classification put bamboo field as part of the forest cover, but farmers use

fertilizers for their bamboo fields, so that they also appear in the Agriculture part in the table.

watersheds (Table 3). Unlike many watersheds in Europe and North America where agricultural lands may comprise more than half of the drainage area, agriculture in Taiwan and other mountainous regions is constrained by the rugged topography. 

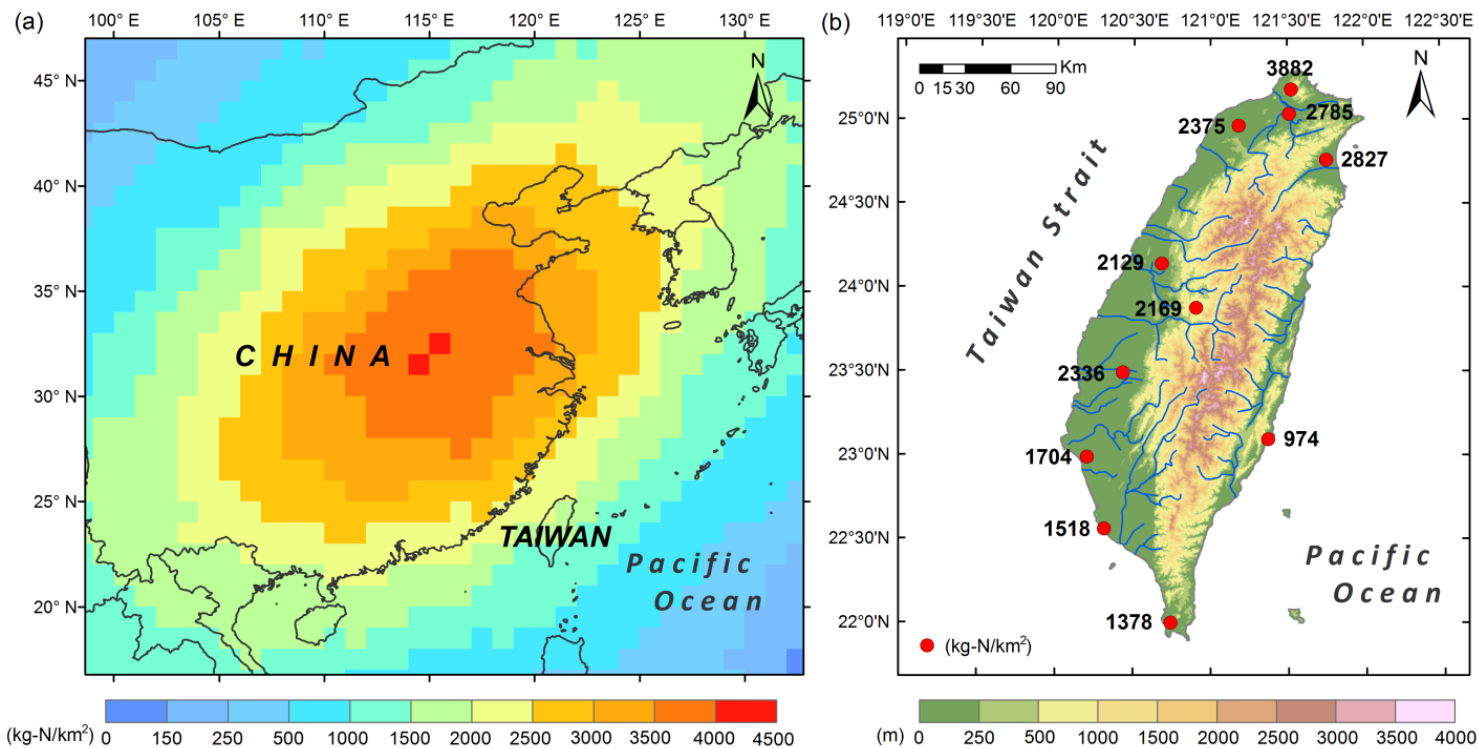

Figure 2. Atmospheric N deposition in East Asia (data set: from ORNL DAAC, NASA, http://daac.ornl.gov) (a). This data set was generated using a global three-dimensional chemistry-transport model (Lelieveld and Dentener, 2000; Jeuken et al. (2001) re-sampled to $1^{\circ} \times 1^{\circ}$ ). The observational long-term $\mathrm{N}$ deposition (including $\mathrm{NO}_{3}$ and $\mathrm{NH}_{4}$ ) in Taiwan (b). The observed wet deposition is used to estimate the dry deposition by an empirical factor of 0.4 based on Lin (unpublished data).

\subsection{N loading}

Atmospheric $\mathrm{N}$ deposition, synthetic fertilizer use, and human emission data are collected and compiled for the determination of the $\mathrm{N}$ inputs and the computation of riverine $\mathrm{N}$ export ratios. Because the emissions from livestock are insignificant, compared to other sources, they are not included in the analysis (see below).

For atmospheric $\mathrm{N}$ deposition, two modeling studies estimate a global average of 145 and $283 \mathrm{~kg} \mathrm{~N} \mathrm{~km}^{-2} \mathrm{yr}^{-1}$ for 1993 and 2050, respectively (Lelieveld and Dentener, 2000; Jeuken et al., 2001). Based on the two studies, $\mathrm{N}$ deposition in East Asia will surge from $\sim 1600 \mathrm{~kg} \mathrm{~N} \mathrm{~km}^{-2} \mathrm{yr}^{-1}$ in 1993 to $\sim 3800 \mathrm{~kg} \mathrm{~N} \mathrm{~km}^{-2} \mathrm{yr}^{-1}$ in 2050 , with a crossyear average of $2700 \mathrm{~kg} \mathrm{~N} \mathrm{~km}^{-2} \mathrm{yr}^{-1}$ (Fig. 2). Our local $\mathrm{N}$ deposition is based on a nation-wide acid rain monitoring network (11 sites) initiated by the Taiwan EPA (Environmental Protection Administration) in 2002. The mean annual wet $\mathrm{N}$ deposition, including $\mathrm{NO}_{3}$ and $\mathrm{NH}_{4}$, was $1515 \mathrm{~kg} \mathrm{~N} \mathrm{~km}^{-2} \mathrm{yr}^{-1}$ between 2007 and 2013, with $\mathrm{NH}_{4}-\mathrm{N}$ accounting for $59 \%$ of the deposition (http://erdb.epa.gov. tw/DataRepository/EnvMonitor/AcidRainAnalysis.aspx). A local empirical study indicates that dry deposition of $\mathrm{N}$ is approximately 23-50\% of wet deposition (Hsu et al., 2013), and thus a factor of 0.4 is used to estimate dry deposition of $\mathrm{N}$ from the island-wide wet deposition monitoring network. From the 11 monitoring sites, we interpolate total $\mathrm{N}$ deposition (wet + dry) for the island using the inverse distanceweighted method with an exponent of 2 . From the interpolation we calculate an island-wide mean total $\mathrm{N}$ deposition of $\sim 2121 \mathrm{~kg} \mathrm{~km}^{-2} \mathrm{yr}^{-1}$, which is consistent with the $\mathrm{N}$ deposition reported by global modeling (Jeuken et al., 2001) and a local observation (Hsu et al., 2013).

$\mathrm{N}$ input from fertilizers is compiled from the crop types and fertilizer applications for each crop type (as partly shown in Table 1). A look-up table for fertilizer applications for each crop type was embedded into the land cover layer (map) so that the crop types could be converted to fertilizer input. Then, we use the individual watershed polygon to clip the land cover layer to estimate fertilizers used in each watershed. $\mathrm{N}$ input from human emissions (wastewater), which are a main source of riverine $\mathrm{N}$, is calculated using a GPDbased estimation proposed by Van Drecht et al. (2009) for per capita $\mathrm{N}$ emissions. The average GDP of Taiwan during 2002-2012 is USD 30000 and the per capita human $\mathrm{N}$ emissions are $\sim 6.42 \mathrm{~kg} \mathrm{~N}$ cap $^{-1} \mathrm{yr}^{-1}$ following the GDPbased estimation. The population size from county-based censuses is converted to county-based population density and then used to estimate the total human emissions. Similar to the calculation of fertilizers used in each watershed, the watershed polygons are used to calculate human emissions for each watershed.

Livestock could be an important source of N. The basic information of livestock in Taiwan is listed in Table S1 in the Supplement, which also compares the numbers of cattle, cow, and swine in Taiwan, the USA, and China. From the table, it is clear that the number and density of cattle and cows in Taiwan are much lower than those in the other two countries. Although the density of swine is much higher in Taiwan than in the other two countries, it is important to note that $\sim 2 / 3$ 
of the island is mountainous with a very limited number of swine. Most pig farms are located in the western plains and are regarded as point sources of pollution, so that wastewater treatment is mandatory. Because the livestock industry is not a primary source of $\mathrm{N}$ in Taiwan and most of the livestock farms are located in the central to southern coastal zones, not in the mountainous region where the studied watersheds are located, livestock excretion is not included in our calculation of $\mathrm{N}$ inputs.

For biological nitrogen fixation (BNF), there are two types of BNF: agricultural BNF and natural BNF. Agricultural $\mathrm{BNF}$ could be a significant $\mathrm{N}$ source. For example, Alfalfa (Medicago sativa L.) can fix $21800 \mathrm{~kg} \mathrm{~N} \mathrm{~km}^{-2} \mathrm{yr}^{-1}$ (McIsaac et al., 2002), which is comparable with that from synthetic fertilizers. A local survey also indicates that the amount of $\mathrm{N}$ from green manure crops is close to the amount of synthetic fertilizers commonly applied in the fields, and farmers typically do not use synthetic fertilizers following the growth of green manure crops (http://www.tndais.gov. tw/search_wg.php). Quality data of agricultural BNF in Taiwan are incomplete and cannot be confidently compiled at an island-wide scale. Therefore, we assume that the agricultural BNF equals the amount of synthetic fertilizers used, and it is already included in our calculation of $\mathrm{N}$ input from fertilizers. For natural BNF, a global synthesis indicates that natural BNF in forest ecosystems varies from 1600 in temperate regions to $2500 \mathrm{~kg} \mathrm{~N} \mathrm{~km}^{-2} \mathrm{yr}^{-1}$ in tropical regions (Cleveland et al., 1999). However, a recent study indicates that BNF in tropical and subtropical regions is not significant and may have been overestimated by more than 5 times in previous studies (Sullivan et al., 2014). The study proposes that natural BNF in tropical forests should be less than $600 \mathrm{~kg} \mathrm{~N} \mathrm{~km}^{-2} \mathrm{yr}^{-1}$. Using this new estimate, the natural BNF would account for less than $5 \%$ of the total $\mathrm{N}$ input in our study, so that it is not included in our analysis.

\subsection{Stream water level and DIN monitoring}

The Water Resources Agency (WRA, http://www.wra.gov. tw/) and the Environmental Protection Administration (http: //www.epa.gov.tw) of Taiwan are in charge of monitoring water quantity and quality, respectively. Streamflow and DIN data from 49 water level monitoring stations (Fig. 1c) in which both water level and water quality data are available during 2002-2012 are used in this study. The water level stations are widely deployed in bridge piers and record water levels automatically. The WRA crew measure the stream cross sections two or three times and flow velocity 10 times per year, and based on these measurements the discharge at each station is obtained several times per year. From these discharge data and the water levels we develop a rating curve for estimating the discharge from the water levels for each of the 49 stations.

For water quality, the EPA sampling crews take water samples on a monthly basis. Temperature, $\mathrm{pH}$, and electri- cal conductivity (EC) are measured in situ; then, the samples are transported to laboratories for chemical and biological analysis, including dissolved oxygen, cations, anions, Escherichia coli (E. coli), and selected heavy metals. For DIN species, ammonium is analyzed on a monthly basis using the 4500- $\mathrm{NH}_{3}$ D. Ammonia-selective electrode method (APHA, 2012). Nitrate and nitrite are analyzed every 3 months using 4500- $\mathrm{NO}_{3}$ I. (APHA, 2012) or ion exchange chromatography (IC). The mean concentrations of DIN species are multiplied by stream discharge (monthly for $\mathrm{NH}_{4}$ and quarterly for nitrate and nitrite) to obtain the DIN fluxes via the global mean approach. The mean DIN concentration, flow-weighted mean concentration, mean discharge during sampling period, and mean daily stream discharge are listed in Table S2 in the Supplement for reference. From the data in the table and some of our previous studies, we conclude that although the quarterly sampling of $\mathrm{NO}_{3}$ and $\mathrm{NO}_{2}$ is not ideal for representing the variation between seasons and between high and low flow periods, the annual fluxes derived from the 10-year data set could still fairly represent the differences between watersheds, which is the main goal of our analysis. A more comprehensive justification of the use of the quarterly samples is provided in Table $\mathrm{S} 2$.

\section{Results and discussions}

\subsection{Riverine DIN concentration and flux}

The island-wide mean DIN concentration and flux calculated from the 49 watersheds are $148.3 \mu \mathrm{M}$ and $3800 \mathrm{~kg} \mathrm{~N} \mathrm{~km}^{-2} \mathrm{yr}^{-1}$, respectively. However, they vary considerably among the three categories of watersheds. The mean annual riverine DIN concentrations are 30,57 , and $330 \mu \mathrm{M}$, and the corresponding exports are 909,1816 , and $8020 \mathrm{~kg} \mathrm{~N} \mathrm{~km}^{-2} \mathrm{yr}^{-1}$ for low, moderately and highly disturbed watersheds, respectively (Fig. 3). For N species, mean $\mathrm{NO}_{3}$ concentration and export increase from $24 \mu \mathrm{M}$ and $725 \mathrm{~kg} \mathrm{~N} \mathrm{~km}^{-2} \mathrm{yr}^{-1}$ for low disturbed watersheds to $100 \mu \mathrm{M}$ and $3243 \mathrm{~kg} \mathrm{~N} \mathrm{~km}^{-2} \mathrm{yr}^{-1}$ for highly disturbed watersheds (Table 4). Similarly, mean $\mathrm{NH}_{4}$ concentration and export increase from $5.6 \mu \mathrm{M}$ and $169 \mathrm{~kg} \mathrm{~N} \mathrm{~km}^{-2} \mathrm{yr}^{-1}$ for low disturbed watersheds to $214 \mu \mathrm{M}$ and $4340 \mathrm{~kg} \mathrm{~N} \mathrm{~km}^{-2} \mathrm{yr}^{-1}$ for highly disturbed watersheds, respectively (Table 4). Nitrite is not shown in the table because it only accounts for a very small proportion $(<0.05)$ of DIN. The patterns and levels of DIN concentrations and fluxes of the 49 watersheds are consistent with results reported for over 20 sub-catchments within two river networks in northern and central Taiwan (Huang et al., 2012; Lee et al., 2014). Note that $\mathrm{NO}_{3}$ is the dominant species for low and moderately disturbed watersheds, but $\mathrm{NH}_{4}$ is the dominant species, accounting for more than $50 \%$ of annual DIN flux for highly disturbed watersheds.

Both $\mathrm{NO}_{3}$ and $\mathrm{NH}_{4}$ exports are significantly and positively correlated with population density $\left(r^{2}=0.19\right.$ for $\mathrm{NO}_{3}$ and 
Table 4. Mean annual $\mathrm{NO}_{3}, \mathrm{NH}_{4}$ and DIN concentrations and riverine fluxes of the three categories of watersheds between 2002 and 2012.

\begin{tabular}{l|cccccc}
\hline \multirow{2}{*}{ Category } & \multicolumn{2}{|c}{$\mathrm{NO}_{3}$} & \multicolumn{2}{c}{$\mathrm{NH}_{4}$} & \multicolumn{2}{c}{ DIN } \\
\cline { 2 - 7 } & Conc. & Flux & Conc. & Flux & Conc. & Flux \\
\hline $\begin{array}{l}\text { Low } \\
\text { disturbed }\end{array}$ & $\begin{array}{c}23.8 \\
(9.9)\end{array}$ & $\begin{array}{c}725 \\
(243)\end{array}$ & $\begin{array}{c}5.60 \\
(3.20)\end{array}$ & $\begin{array}{c}169 \\
(86.8)\end{array}$ & $\begin{array}{c}29.9 \\
(11.0)\end{array}$ & $\begin{array}{c}909 \\
(285)\end{array}$ \\
\hline $\begin{array}{l}\text { Moderately } \\
\text { disturbed }\end{array}$ & 50.2 & 1600 & 5.70 & 182 & 56.9 & 1820 \\
\hline Highly & $(31.1)$ & $(854)$ & $(2.80)$ & $(87.9)$ & $(31.5)$ & $(854)$ \\
disturbed & $(42.9)$ & 3240 & 214 & 4340 & 329 & 8020 \\
\hline
\end{tabular}

Parentheses indicate the standard deviation of the individual category. Unit for concentration and flux are $\mu \mathrm{M}$ and $\mathrm{kg} \mathrm{N} \mathrm{km}^{-2}$, respectively.

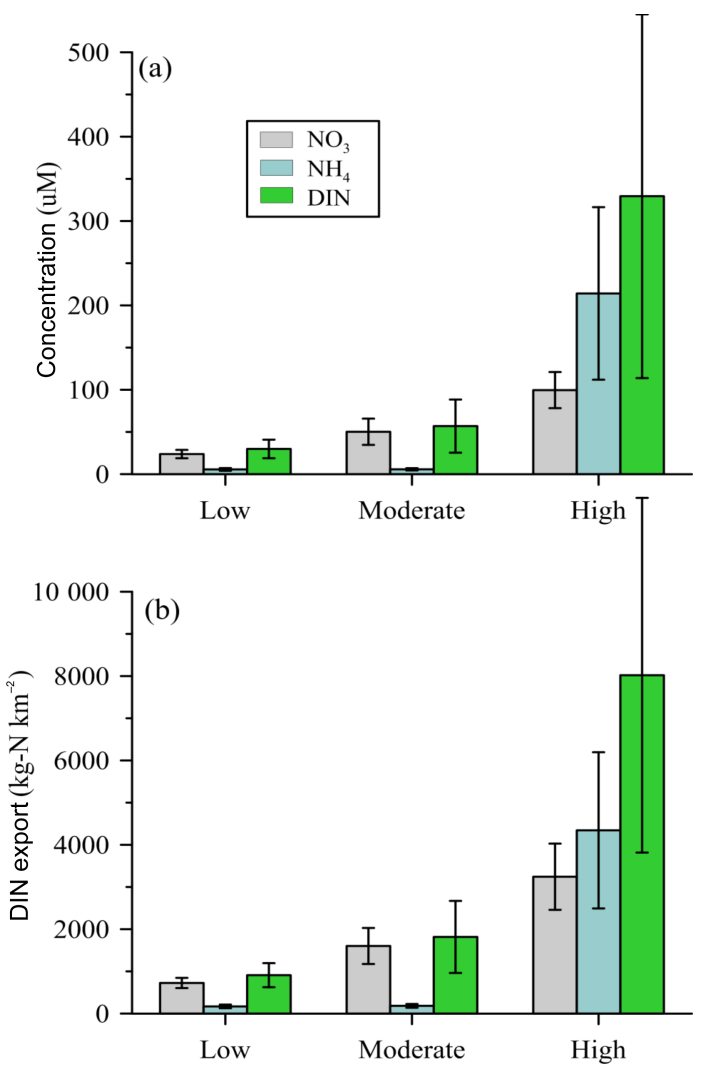

Figure 3. Mean riverine DIN concentration (a) and annual export (b) of the low, moderately, and highly disturbed watersheds during 2002-2012. The gray, sky blue, and green bars represent the $\mathrm{NO}_{3}$, $\mathrm{NH}_{4}$, and DIN of the three classes. Standard deviation for each bar is given as well.

0.18 for $\mathrm{NH}_{4}$, both $p$ values <0.01) and the proportion of agricultural land cover $\left(r^{2}=0.34\right.$ for $\mathrm{NO}_{3}$ and 0.50 for $\mathrm{NH}_{4}$, both $p$ values <0.01) (Fig. 4). The intensive cropping system and dense population likely contribute to the 10 -fold greater DIN export at the highly disturbed watersheds relative to the low disturbed watersheds. While the relationship
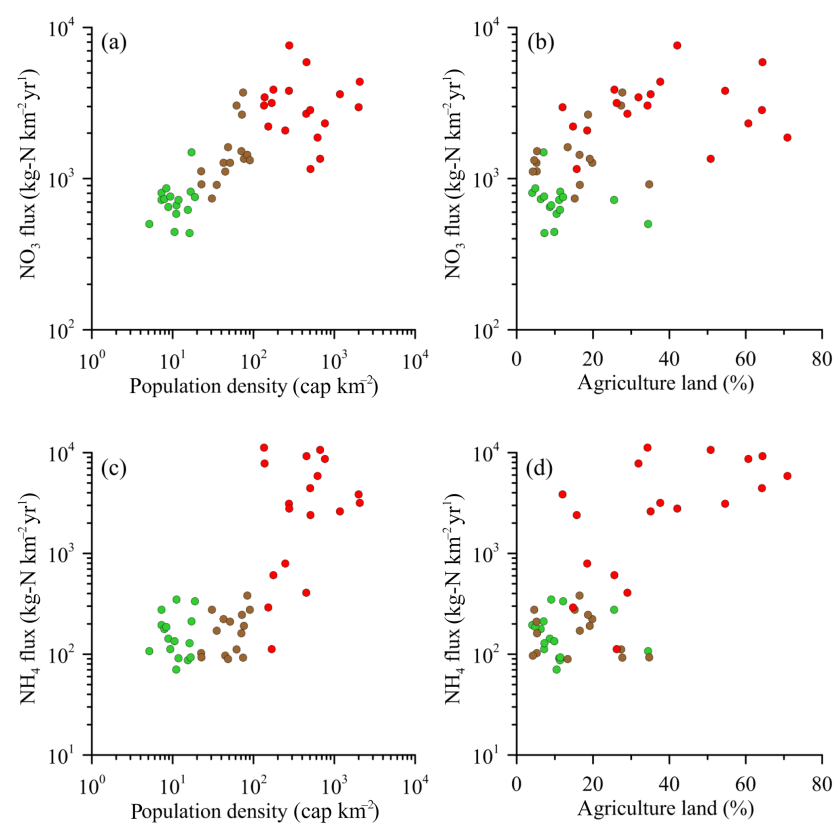

Figure 4. Scatterplot of $\mathrm{NO}_{3}$ and $\mathrm{NH}_{4}$ export associated with population density, (a) and (b), and relative agricultural land cover, (c) and (d). The green, brown, and red dots show the low, moderately, and highly disturbed watersheds, respectively. The $r$-squared values for (a), (b), (c), and (d) are $0.19,0.34,0.18$, and 0.50 , with $p$ values $<0.01$, respectively.

between population density and $\mathrm{NO}_{3}$ and $\mathrm{NH}_{4}$ export is very similar, $\mathrm{NH}_{4}$ increases more dramatically than $\mathrm{NO}_{3}$ with increases in relative agricultural land cover (Fig. 4). Across the three categories of watersheds, $\mathrm{NO}_{3}$ export increases gradually with increases in both agricultural land cover and population density. By contrast, $\mathrm{NH}_{4}$ export does not change much from low to moderately disturbed watersheds (Fig. 4), but increases dramatically with increasing agricultural land cover and population density in highly disturbed watersheds, indicating that most of the elevated $\mathrm{NH}_{4}$ export likely comes from domestic wastewater and agricultural activities. 


\subsection{Total $\mathbf{N}$ input}

Mean total annual $\mathrm{N}$ input increases from $4893 \mathrm{~kg} \mathrm{~N} \mathrm{~km}^{-2} \mathrm{yr}^{-1}$ for the low disturbed watersheds, $6578 \mathrm{~kg} \mathrm{~N} \mathrm{~km}^{-2} \mathrm{yr}^{-1}$ for moderately disturbed watersheds, to $16636 \mathrm{~kg} \mathrm{~N} \mathrm{~km}^{-2} \mathrm{yr}^{-1}$ for highly disturbed watersheds (Table 5). Because atmospheric $\mathrm{N}$ deposition is in a small range across the three categories of watersheds (2033$2224 \mathrm{~kg} \mathrm{~N} \mathrm{~km}^{-2} \mathrm{yr}^{-1}$ ), it could not cause the large increases in total $\mathrm{N}$ input from low to highly disturbed watersheds. Instead the increases are mainly from fertilizer applications and human emissions (Table 5). Assuming synthetic fertilizers are applied only in agriculture lands, the input of $\mathrm{N}$ from fertilizers in each percent of agricultural land (a total of 11,16 , and $38 \%$ in low, moderately, and highly disturbed watersheds, respectively) increases only slightly from $236 \mathrm{~kg} \mathrm{~N} \mathrm{~km}^{-2} \mathrm{yr}^{-1}$ in low disturbed watersheds, $254 \mathrm{~kg} \mathrm{~N} \mathrm{~km}^{-2} \mathrm{yr}^{-1}$ in moderately disturbed watersheds, to $279 \mathrm{~kg} \mathrm{~N} \mathrm{~km}^{-2} \mathrm{yr}^{-1}$ in highly disturbed watersheds. In contrast, assuming human emissions are entirely from built-up lands, the input of $\mathrm{N}$ from human emissions of each percent of built-land increases dramatically from $24 \mathrm{~kg} \mathrm{~N} \mathrm{~km}^{-2} \mathrm{yr}^{-1}$ in low disturbed watersheds, $118 \mathrm{~kg} \mathrm{~N} \mathrm{~km}^{-2} \mathrm{yr}^{-1}$ in moderately disturbed watersheds, to $349 \mathrm{~kg} \mathrm{~N} \mathrm{~km}^{-2} \mathrm{yr}^{-1}$ in highly disturbed watersheds. The increases in $\mathrm{N}$ input from per unit built-up land as its contribution to total watershed area increases possibly reflect disproportional increases in population density as the proportion of built-up land increases, which is often associated with higher degrees of urbanization. The result suggests that population density control and/or the effectiveness of wastewater treatment could be important control measures of $\mathrm{N}$ emissions and the resultant DIN export.

\subsection{River DIN exports in Taiwan and the world}

Since the 1960s global $\mathrm{N}$ flux from land to ocean has risen 2 -fold (Howarth et al., 2002). Regionally, it has increased $\sim$ 4-fold in the Mississippi River basin, 8-fold in the northeastern USA, and more than 10-fold for the rivers draining into the North Sea (Howarth et al., 2002). Dumont et al. (2005) reported that the global DIN export to coastal waters is $\sim 25 \mathrm{Tg} \mathrm{Nyr}^{-1}$, with more than $60 \%$ stemming from anthropogenic sources. Given the global land area of 120 million $\mathrm{km}^{2}$, the average DIN export per unit land area is $208 \mathrm{~kg} \mathrm{~N} \mathrm{~km}^{-2} \mathrm{yr}^{-1}$. Our estimate of the riverine DIN export for Taiwan is $\sim 3800 \mathrm{~kg} \mathrm{~N} \mathrm{~km}^{-2} \mathrm{yr}^{-1}, 18$ times the global average. Generally, the riverine $\mathrm{N}$ export is strongly affected by climatic factors and human activities, increasing from temperate to tropical climates and from pristine to disturbed watersheds (Howarth, 1998; Smith et al., 2005; Seitzinger et al., 2005). For example, the riverine $\mathrm{N}$ export is $76 \mathrm{~kg} \mathrm{~N} \mathrm{~km}^{-2} \mathrm{yr}^{-1}$ for the sparsely populated watersheds in northern Canada, but reaches $1450 \mathrm{~kg} \mathrm{~N} \mathrm{~km}^{-2} \mathrm{yr}^{-1}$ for the developed watersheds of the North Sea (Howarth et al., 1996).

He et al. (2011) reported a positive relationship between DIN export and runoff, population density and proportion of agricultural land cover at the global scale. Adding Taiwan to the global pictures reveals an interesting phenomenon (Fig. 5). Globally the DIN export increases with increases in runoff and Taiwan is clearly on the very high end of both runoff and DIN export. The global pattern exists regardless of the large differences in the efficiency of wastewater treatment among regions and among countries of the same region. Thus, in spite of the large differences in $\mathrm{N}$ inputs from wastewater, agriculture and industrial activities, runoff still plays an important role in DIN export.

Interestingly, few sites in the study of global $\mathrm{N}$ export by $\mathrm{He}$ et al. (2011) have annual runoff greater than $1 \mathrm{~m} \mathrm{r}^{-1}$, while the mean runoff of the 49 watersheds in our study is $2 \mathrm{~m} \mathrm{r}^{-1}$. High runoff is not limited to Taiwan, as many tropical and subtropical forested watersheds show a similar pattern. For example, the forested watersheds in northern Australia also have high runoff $(1.96 \mathrm{~m})$ and high DIN export (2300 $\mathrm{kg} \mathrm{N} \mathrm{km}^{-2} \mathrm{yr}^{-1}$ ) (Hunter et al., 2008). Compared to the global-scale variation of runoff $(0.01-1.0 \mathrm{~m})$, the variation within Taiwan is relatively small $(1.5-2.5 \mathrm{~m})$, but DIN export of the 49 watersheds varies largely $(\sim 900$ to $\sim 8000 \mathrm{~kg} \mathrm{~N} \mathrm{~km}^{-2} \mathrm{yr}^{-1}$ ) even compared to the global picture ( 10-2000 kg N km$\left.{ }^{-2} \mathrm{yr}^{-1}\right)$ (Fig. 5). However, even $900 \mathrm{~kg} \mathrm{~N} \mathrm{~km}^{-2} \mathrm{yr}^{-1}$ is on the high end of the global scale. Thus, adding Taiwan to the figure of global $\mathrm{N}$ export fills the gap for regions with both high runoff and high DIN export.

Among the three factors population density, agriculture activity, and runoff, only population density shows a consistent positive relationship with DIN export at both the global scale and our island scale (Fig. 5). Runoff is a good predictor only at the global scale, and agriculture is a good predictor only at the island scale (Fig. 5). The lack of predictability of runoff on DIN export in Taiwan might be due to the limited variation in runoff relative to the 10-fold differences in DIN export (Fig. 5). The lack of predictability of agriculture land cover on DIN export at the global scale is not surprising because differences in farming practices (e.g., levels of fertilization and soil disruption) between regions could lead to very different patterns of DIN export even when the proportion of agriculture land cover is similar. In general, fertilizers are applied at much larger quantities in regions with intensive farming systems such as China, Taiwan, and Thailand than in regions with extensive farming systems such as North America, Europe, and Australia. For example, in rice fields $\mathrm{N}$ is applied at approximately $418 \mathrm{~kg} \mathrm{ha}^{-1} \mathrm{yr}^{-1}$ in Taiwan ( $\sim 200 \mathrm{~kg} \mathrm{ha}^{-1}$ for a harvest; FAO, 2002), $194 \mathrm{~kg} \mathrm{ha}^{-1} \mathrm{yr}^{-1}$ in China, but only $135 \mathrm{~kg} \mathrm{ha}^{-1} \mathrm{yr}^{-1}$ in California, USA (Yan et al., 2003). As a result of such large differences, DIN export from a watershed with $100 \%$ of rice fields in North America may not be different from the export of a watershed with $32 \%$ of rice fields in East Asia. Due to the dif- 
Table 5. Nitrogen inputs, riverine output, and riverine export ratios of the three categories of watersheds.

\begin{tabular}{l|cccc}
\hline & Low disturbed & Moderately disturbed & Highly disturbed & All watersheds \\
\hline Atmospheric deposition & 2220 & 2030 & 2200 & 2160 \\
Synthetic fertilizer & 2600 & 4190 & 10600 & 6020 \\
a'Human emission & 73.4 & 354 & 3840 & 1540 \\
Total input & 4900 & 6580 & 16600 & 9720 \\
\hline Riverine DIN output & 909 & 1820 & 8020 & 3800 \\
\hline b Averaged export ratio & 0.18 & 0.27 & 0.42 & 0.30 \\
${ }^{c}$ Regressive export ratio & 0.06 & 0.20 & 0.53 & 0.51 \\
\hline
\end{tabular}

Unit for inputs and output is $\mathrm{kg} \mathrm{N} \mathrm{km}^{-2} \mathrm{yr}^{-1}$.

${ }^{a}$ Human emissions are calculated from per capita emissions using GDP-based estimation proposed by Van Drecht et al. (2009).

${ }^{b}$ Averaged export ratio is the arithmetical mean of the export ratios in the category.

${ }^{c}$ Regressive export ratio indicates the regressive slope of DIN output with DIN input in the category.

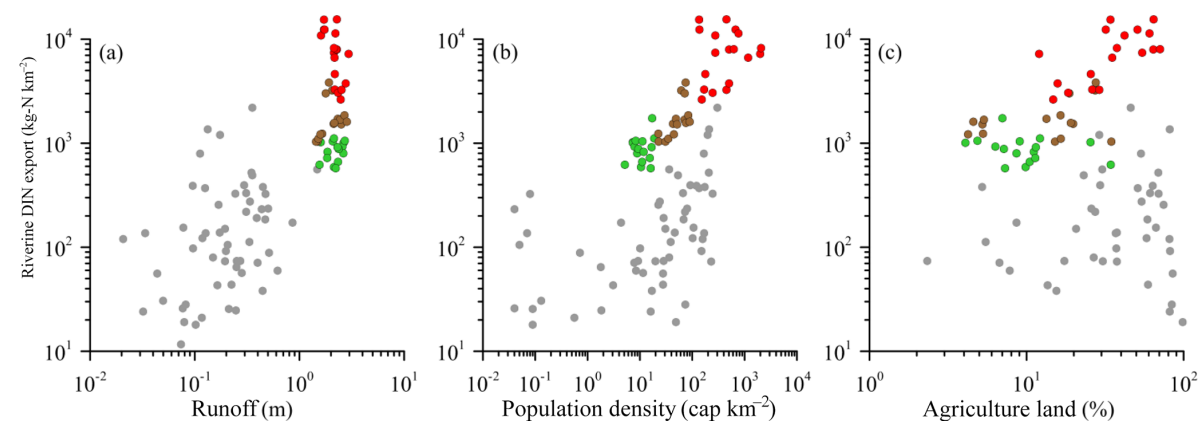

Figure 5. Scatterplot of riverine DIN export associated with runoff (a), population density (b), and relative agricultural land cover (c). The gray dots represent the global river data retrieved from He et al. (2011). The green, brown, and red dots show the low, moderately, and highly disturbed watersheds, respectively.

ferences in farming systems, the relationship between DIN export and agricultural land cover is likely comparable only between regions with similar management practices (Huang et al., 2012). For global assessments, the amount of $\mathrm{N}$ fertilizer application coupled with the proportion of agricultural land cover would be necessary for predicting riverine DIN export from agriculture.

From the global assessment by $\mathrm{He}$ et al. (2011), $\mathrm{NH}_{4}-\mathrm{N}$ export is 10 to $100 \%$ of the total $\mathrm{NO}_{3}-$ and $\mathrm{NO}_{2}-\mathrm{N}$ export in large rivers around the world, and this range also applies to the low and moderately disturbed watersheds in Taiwan (Fig. 6). However, while only 1 of the 49 watersheds has a $\mathrm{NH}_{4}$ to $\mathrm{NO}_{3}+\mathrm{NO}_{2}$ ratio less than 0.1 , approximately $50 \%$ (16/34) of the rivers in He et al. (2011) had a ratio less than 0.1. Moreover, none of the rivers in He et al. (2011) has a ratio greater than 1.0 , but 10 of the highly disturbed watersheds in Taiwan have a ratio greater than 1.0, and one of them even reaches 10 . Globally $\mathrm{NO}_{3}$ is the predominant species of DIN export, partly because $\mathrm{NO}_{3}$ is more stable than $\mathrm{NH}_{4}$, which is easily oxidized or removed though the treatment processes. In the highly disturbed watersheds, the average DO is $\sim 6.8 \mathrm{mg} \mathrm{L}^{-1}$ for watersheds with a $\mathrm{NH}_{4}$ to $\mathrm{NO}_{3}+\mathrm{NO}_{2}$ ratio greater than 1 , and $\sim 8.4 \mathrm{mg} \mathrm{L}^{-1}$ for the

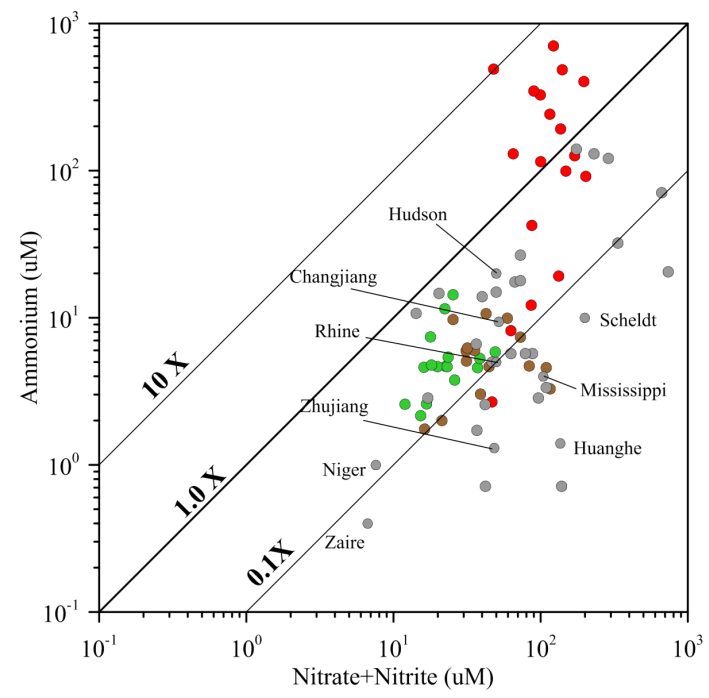

Figure 6. The DIN composition of large rivers around the world (He et al., 2011) and the 49 rivers in Taiwan. The green, brown, and red dots represent the rivers of the low, moderately, and highly disturbed watersheds. 

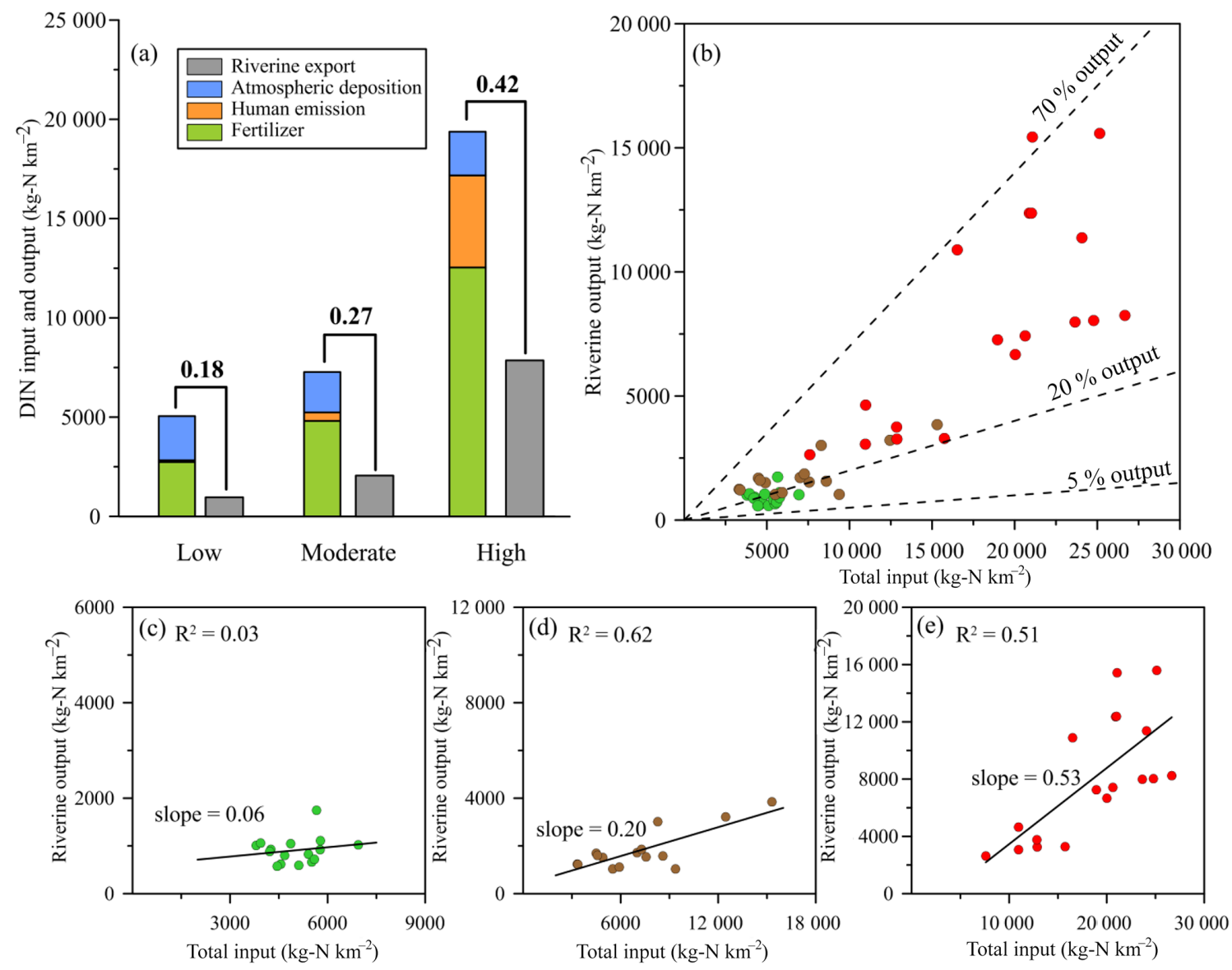

Figure 7. Nitrogen input and riverine output in the low, moderately, and highly disturbed watersheds (a). Riverine DIN export against the total nitrogen input (b). The regressive slope of riverine output for the low disturbed (green dots) (c), moderately (brown dots) (d), and highly disturbed (red dots) (e) watersheds.

remaining watersheds suggesting that oxidation potential is important in determining $\mathrm{NH}_{4}$ relative to $\mathrm{NO}_{3}+\mathrm{NO}_{2}$ concentration in streamwater. The highly disturbed watersheds are at lower elevations that have higher temperatures than low and moderately disturbed watersheds, and high temperatures would facilitate the oxidation of $\mathrm{NH}_{4}$. Thus, the dominance of $\mathrm{NH}_{4}$ in DIN export for the highly disturbed watersheds regardless of their greater $\mathrm{NH}_{4}$ oxidation potential is likely due to high $\mathrm{NH}_{4}$ input.

Using ${ }^{15} \mathrm{~N}$ isotopic analysis, Peng et al. (2012) found very limited $\mathrm{NH}_{4}$ removal in upstream watersheds of Taiwan, and suggested that $\mathrm{NH}_{4}$ export from these watersheds to streams is very limited. Water residence time in Taiwan is, in general, very short due to the small drainage area $\left(<1000 \mathrm{~km}^{2}\right)$ and steep slopes $(>30 \%)$ and is unfavorable for $\mathrm{NH}_{4}$ removal (Halbfaß et al., 2010) because of the limited time available for ammonia oxidization and/or assimilation. Thus, the very low $\mathrm{NH}_{4}$ content in the low and moderately disturbed watersheds suggests that nitrification and vegetation uptake is substantial compared to mineralization in these watersheds. In contrast, our highly disturbed watersheds have high $\mathrm{NH}_{4}$ concentrations and fluxes (Figs. 3 and 4). Although given that the high $\mathrm{NH}_{4}$ concentrations biogeochemical processes such as nitrification may transform a substantial portion of $\mathrm{NH}_{4}$ (Venohr et al., 2005), it is very likely insufficient for transforming most of the $\mathrm{NH}_{4}$ in the highly disturbed watersheds. The $\mathrm{NH}_{4}$ concentration (over $300 \mu \mathrm{M}$ ) in the urban drainage systems of Taiwan is very high (Lee et al., 2014) due to the low proportion of households connected to a sewage system. The high human emissions and the short water residence time will likely result in the dominance of $\mathrm{NH}_{4}$ in downstream watersheds unless effective $\mathrm{NH}_{4}$ removal measures are applied in wastewater treatments.

\subsection{Riverine $\mathrm{N}$ export ratio}

Although both total $\mathrm{N}$ input and output increase from low to highly disturbed watersheds, the increases are greater for output (from 575 to $15689 \mathrm{~kg} \mathrm{~N} \mathrm{~km}^{-2} \mathrm{yr}^{-1}$ ) than input (from 3805 to $26668 \mathrm{~kg} \mathrm{~N} \mathrm{~km}^{-2} \mathrm{yr}^{-1}$ ) (Table 5). As a result the measured DIN export ratio increases from 0.18 (ranging from 0.05 to 0.20 ) for the low disturbed watersheds, 0.27 
( 0.11 to 0.38$)$ for the moderately disturbed watersheds, to 0.42 ( 0.21 to 0.73 ) for the highly disturbed watersheds, with an average of 0.30 (Table 5). It appears that the highly disturbed watersheds have greater DIN export both in absolute quantity (per unit area) and relative to $\mathrm{N}$ input than less disturbed watersheds. Simple linear regression models indicate that the slopes between riverine DIN export and $\mathrm{N}$ input for the three categories are $0.06,0.20$, and 0.53 , with $R^{2}$ of 0.03 , 0.62 , and 0.51 from low, moderately, and highly disturbed watersheds, respectively (Fig. 7c, d, and e). The regression models support the fact that, with per unit increases in $\mathrm{N}$ input, the rise in DIN export is greater at more disturbed watersheds than less disturbed watersheds. Increases in DIN output in absolute quantity could be at least partially explained by greater $\mathrm{N}$ inputs, but other factors must have contributed to the greater DIN export ratios at the more disturbed watersheds.

Although there is an overall increases in the DIN export ratio with increases in $\mathrm{N}$ input, such a relationship does not exist for the low disturbed watersheds in which the DIN export ratio is not significantly related to $\mathrm{N}$ input (Fig. $7 \mathrm{~b}$ ). Differences in runoff ratios are often used to explain the differences in export ratios because greater runoff ratios would lead to greater DIN export ratios (Huang et al., 2012; Lin et al., 2015). Watersheds with steeper slopes typically have a shorter water residence time and greater runoff ratios than watersheds with less steep slopes. However, regardless of the substantial differences in slope steepness (53-76\%) among our low disturbed watersheds, runoff and runoff ratio show very limited differences between the watersheds.

The capacity of plant $\mathrm{N}$ uptake and the amount of $\mathrm{N}$ that can be held in the soil (e.g., $\mathrm{NH}_{4}$ in the inter-layer space of Vermiculite and Montmorillonite and $\mathrm{N}$ in soil humus) greatly determine ecosystem $\mathrm{N}$ retention capacity. If $\mathrm{N}$ input is less than the retention capacity, then DIN export may be unrelated to $\mathrm{N}$ input because most of the additional $\mathrm{N}$ input is retained within the watershed until it exceeds the retention capacity. This is probably the case for our low disturbed watersheds in which the riverine DIN export is $\sim 900 \mathrm{~kg} \mathrm{~N} \mathrm{~km}^{-2} \mathrm{yr}^{-1}$, which is relatively small compared to the total input of 2000 to $8000 \mathrm{~kg} \mathrm{~N} \mathrm{~km}^{-2} \mathrm{yr}^{-1}$.

The high DIN export ratios in alpine watersheds of the Front Range of Colorado with low atmospheric deposition in comparison to other regions where watersheds retain more $\mathrm{N}$ regardless of higher $\mathrm{N}$ input can be used to illustrate the role of biological uptake (Campbell et al., 2000). The $\mathrm{N}$ export ratio in alpine watersheds in Colorado ranges from 0.55 to 0.71 , although atmospheric deposition was only 320 $550 \mathrm{~kg} \mathrm{~N} \mathrm{~km}^{-2} \mathrm{yr}^{-1}$ (Campbell et al., 2000), and by contrast the $\mathrm{N}$ export ratio for Baltimore LTER (long-term ecological research) sites is less than 0.1, although the input of $1120 \mathrm{~kg} \mathrm{~N} \mathrm{~km}^{-2} \mathrm{yr}^{-1}$ was much higher (Groffman et al., 2004; Kaushal et al., 2008). Campbell et al. (2000) suggested that the mature alpine forests in Colorado may have shown symptoms of advanced stages of nitrogen excess, so that the forests have a very limited capacity to retain $\mathrm{N}$ in spite of the low atmospheric $\mathrm{N}$ deposition.

Our low disturbed watersheds, which are mainly distributed in the mountain ranges, are characterized by high atmospheric $\mathrm{N}$ input, and the mean riverine DIN export ratio $(0.18)$ is slightly less than those of large rivers around the world (0.2-0.25) (Howarth et al., 2006). The low disturbed watersheds are predominately covered by natural forests. Prior to the 1980 s, forests were under extensive exploitation island-wide; only forests at very high elevations with very limited accessibility were not heavily deforested. The largescale deforestation led to serious consequences for soil and water conservation, including many catastrophic landslides and debris flows. Then, due to public pressure, deforestation largely stopped in late 1980 and was entirely prohibited in 1991. Many low- to mid-elevation forests are undergoing secondary growth. It is likely that the secondary forests are still capable of taking up large amounts of $\mathrm{N}$, leading to the low DIN export ratio and the lack of a close relationship between $\mathrm{N}$ input and output. If forest growth is indeed key to the low DIN export and export ratio, then reforestation could be an effective management practice to reduce DIN export and therefore reduce the risk of downstream eutrophication, especially if the trees are regularly harvested before the forest matures and the ability to take up nutrients declines.

The moderately and highly disturbed watersheds show a linear relationship between DIN export and total $\mathrm{N}$ input, with a slope of 0.2 for moderately disturbed watersheds and 0.53 for highly disturbed watersheds (Fig. $7 \mathrm{~d}$ and e). The positive linear relationships suggest that the watersheds are unable to retain most of the increased $\mathrm{N}$ input and the likeliness of $\mathrm{N}$ excess (Liu et al., 2010). The greater export ratios of moderately disturbed watersheds than low disturbed watersheds most likely relate to their greater agricultural land cover (16\% compared to $11 \%$ in low disturbed watersheds) because the proportion of built-up lands is similar between the two categories of watersheds. In addition, compared to the low disturbed watersheds, the moderately disturbed watersheds have more crops that are heavily fertilized (see Sect. 3.2), and this may have also contributed to their greater export ratios. Our results suggest that agricultural lands have a lower $\mathrm{N}$ retention capacity than forests. Although agricultural lands only cover a small proportion of the watersheds, they have a high impact on riverine DIN export. Thus, concentrating management efforts (e.g., erosion control, precision fertilization) on agricultural lands could significantly reduce DIN export. The highly disturbed watersheds had much larger DIN export ratios than the moderately disturbed watersheds, likely a result of higher population density and agriculture intensity.

The considerable variation of export ratios, $0.21-0.73$, of the highly disturbed watersheds may result from their differences in wastewater treatment efficiencies and cropping systems. In addition, the very high DIN export ratios in the highly disturbed watersheds suggest that the $\mathrm{N}$ input is trans- 
ported by riverine systems very efficiently, and as such the eutrophication threat is high downstream. The high export ratios also suggest that the highly disturbed watersheds are probably at more advanced stages of $\mathrm{N}$ excess and that the current removal processes (e.g., denitrification, vegetation uptake) cannot compensate for the increasing $\mathrm{N}$ additions (Downing et al., 1999). Additionally, recent studies report increases in rainfall intensity in Taiwan as a result of recent climate change (Huang et al., 2014; Liu et al., 2009). Increases in rainfall intensity would shorten water residence time and therefore further enhance riverine DIN export. Thus, increasing the proportion of households connected to sewage systems and improving the effectiveness of new and existing systems would probably be the most effective measure to reduce riverine DIN export in Taiwan and other regions with high population densities.

\section{Concluding remarks}

We characterized riverine DIN export of subtropical watersheds in Taiwan using a total of 49 watersheds classified as low, moderately, and highly disturbed based on population densities (from $<20$ to $>200 \mathrm{cap} \mathrm{km}^{-2}$ ). The average riverine DIN export is $\sim 3800 \mathrm{~kg} \mathrm{~N} \mathrm{~km}^{-2} \mathrm{yr}^{-1}$, approximately 18 times the global average, and is attributable to the high runoff, high atmospheric $\mathrm{N}$ deposition, intensive crop systems, and high human emissions. Because the runoff varies only by 2 -fold and atmospheric deposition varies less than $30 \%$, the $\sim 10$ times greater DIN export of highly disturbed watersheds ( $8000 \mathrm{~kg} \mathrm{~N} \mathrm{~km}^{-2} \mathrm{yr}^{-1}$ ) compared to low disturbed watersheds $\left(900 \mathrm{~kg} \mathrm{~N} \mathrm{~km}^{-2} \mathrm{yr}^{-1}\right)$ likely results from their differences in inputs from agricultural lands, human emissions, and watershed $\mathrm{N}$ retention capacity. Nitrate is the dominant $\mathrm{N}$ species for large rivers around the world and our low and moderately disturbed watersheds, whereas $\mathrm{NH}_{4}$ is the dominant species in the highly disturbed watersheds, possibly due to high human emissions and the short water residence time, which is unfavorable for ammonia removal processes. The high $\mathrm{N}$ export poses a risk of eutrophication to downstream ecosystems including coastal waters.

Our averaged riverine DIN export ratios, $0.30-0.51$, are higher than those $(0.2-0.25)$ of many major rivers around the globe. Even the low disturbed watersheds have very high atmospheric $\mathrm{N}$ input $\left(2200 \mathrm{~kg} \mathrm{~N} \mathrm{~km}^{-2} \mathrm{yr}^{-1}\right)$. However, they only export $6-18 \%$ of the $\mathrm{N}$ input, implying that the watersheds have high $\mathrm{N}$ use efficiency and/or retention capacity possibly due to uptake by the still growing secondary forests. The moderately disturbed watersheds export $20-27 \%$ of the total $\mathrm{N}$ input (3330-15315 $\mathrm{kg} \mathrm{N} \mathrm{km}^{-2} \mathrm{yr}^{-1}$ ). The positive linear relationship between DIN export and total $\mathrm{N}$ input indicates the degradation of nitrogen retention capacity and symptoms of nitrogen excess. The riverine DIN export ratios of the highly disturbed watersheds are very high $(0.42-$ 0.53 ) and could be attributed to synergistic effects of high population density and agricultural activities. The high $\mathrm{N}$ export ratios indicate that the human-associated $\mathrm{N}$ inputs are transported to riverine systems very efficiently and that the systems may be in advanced stages of $\mathrm{N}$ excess. The result also indicates that current in-stream removal processes (e.g., denitrification and uptake) cannot effectively reduce riverine $\mathrm{N}$ export. Increasing the proportion of households connected to sewage systems and improving the effectiveness of the sewage systems are important considerations for reducing $\mathrm{N}$ export.

\section{The Supplement related to this article is available online at doi:10.5194/bg-13-1787-2016-supplement.}

Acknowledgements. This study was sponsored by NSC Taiwan grants (NSC 103-2116-M-002-020, 102-2923-M-002-001-MY3, 103-2621-M-002-016) and project ECATA (grant number I 1396B16) funded by FWF (the Austrian Science Fund).

Edited by: B. A. Pellerin

\section{References}

Aber, J. D., Nadelhoffer, K. J., Steudler, P., and Melillo, J. M.: Nitrogen Saturation in Northern Forest Ecosystems, Bioscience, 39, 378-386, 1989.

Aber, J. D., McDowell, W., Nadelhoffer, K., Magill, A., Berntson, G., Kamakea, M., McNulty, S., Currie, W., Rustad, L., and Fernandez, I.: Nitrogen saturation in temperate forest ecosystems Hypotheses revisited, Bioscience, 48, 921-934, 1998.

American Public Health Association (APHA), American Water Works Association \& Water Pollution Control Federation. Standard method for the examination water and wastewater, 22nd., Method 4500-NO3- I., 4-129-4-131, APHA, Washington, DC, USA, 2012.

Brown, L. R., Cuffney, T. F., Coles, J. F., Fitzpatrick, F., McMahon, G., Steuer, J., Bell, A. H., and May, J. T.: Urban streams across the USA: lessons learned from studies in 9 metropolitan areas, J. N. Am. Benthol. Soc., 28, 1051-1069, 2009.

Campbell, D. H., Baron, J. S., Tonnessen, K. A., Brooks, P. D., and Schuster, P. F.: Controls on nitrogen flux in alpine/subalpine watersheds of Colorado, Water Resour. Res., 36, 37-47, 2000.

Cleveland, C. C., Townsend, A. R., Schimel, D. S., Fisher, H., Howarth, R. W., Hedin, L. O., Perakis, S. S., Latty, E. F., Von Fischer, J. C., Elseroad, A., and Wasson, M. F.: Global patterns of terrestrial biological nitrogen $\left(\mathrm{N}_{2}\right)$ fixation in natural ecosystems, Global Biogeochem. Cy., 13, 623-645, 1999.

Conley, D. J., Paerl, H. W., Howarth, R. W., Boesch, D. F., Seitzinger, S. P., Havens, K. E., Lancelot, C., and Likens, G. E.: Controlling eutrophication: nitrogen and phosphorus, Science, 323, 1014-1015, 2009.

Downing, J. A., Osenberg, C. W., and Sarnelle, O.: Meta-Analysis of marine nutrient-enrichment experiments: Variation in the 
magnitude of nutrient limitation, Ecology, 80, 1157==1167, doi:10.1890/0012-9658(1999)080[1157:MAOMNE]2.0.CO;2, 1999.

Dumont, E., Harrison, J. A., Kroeze, C., Bakker, E. J., and Seitzinger, S. P.: Global distribution and sources of dissolved inorganic nitrogen export to the coastal zone: Results from a spatially explicit, global model, Global Biogeochem. Cy., 19, GB4S02, doi:10.1029/2005GB002488, 2005.

Environmental Protection Administration (EPA): Environmental Water Quality Information, Environmental Protection Administration, Executive Yuan, Taiwan, available at: http://wq.epa.gov. tw/ (last access: 21 August 2013), 2002.

Food and Agriculture Organization (FAO): Fertilizer use by crop in Taiwan Province of China, Rome, Italy, 2002.

Fitzpatrick, F. A., Harris, M. A., Arnold, T. L., and Richards, K. D.: Urbanization influences on aquatic communities in northeastern Illinois streams, J. Am. Water Resour. As., 40, 461-475, 2004.

Galloway, J. N., Dentener, F. J., Capone, D. G., Boyer, E. W., Howarth, R. W., Seitzinger, S. P., Asner, G. P., Cleveland, C. C., Green, P. A., Holland, E. A., Karl, D. M., Michaels, A. F., Porter, J. H., Townsend, A. R., and Vörosmarty, C. J.: Nitrogen cycles: past, present, and future, Biogeochemistry, 70, 153-226, 2004.

Galloway, J. N., Townsend, A. R., Erisman, J. W., Bekunda, M., Cai, Z. C., Freney, J. R., Martinelli, L. A., Seitzinger, S. P., and Sutton, M. A.: Transformation of the nitrogen cycle: Recent trends, questions, and potential solutions, Science, 320, 889-892, 2008.

Gao, W., Howarth, R. W., Hong, B., Swaney, D. P., and Guo, H. C.: Estimating net anthropogenic nitrogen inputs (NANI) in the Lake Dianchi basin of China, Biogeosciences, 11, 4577-4586, doi:10.5194/bg-11-4577-2014, 2014.

Groffman, P. M., Law, N. L., Belt, K. T., Band, L. E., and Fisher, G. T.: Nitrogen Fluxes and Retention in Urban Watershed Ecosystems, Ecosystems, 7, 393-403, 2004.

Gruber, N. and Galloway, J. N.: An Earth-system perspective of the global nitrogen cycle, Nature, 451, 293-296, 2008.

Halbfaß, S., Gebel, M., and Bürger, S.: Modelling of long term nitrogen retention in surface waters, Adv. Geosci., 27, 145-148, doi:10.5194/adgeo-27-145-2010, 2010.

He, B., Kanae, S., Oki, T., Hirabayashi, Y., Yamashiki, Y., and Takara, K.: Assessment of global nitrogen pollution in rivers using an integrated biogeochemical modeling framework, Water Res., 45, 2573-2586, 2011.

Howarth, R. W.: An assessment of human influences on fluxes of nitrogen from the terrestrial landscape to the estuaries and continental shelves of the North Atlantic Ocean, Nutr. Cycl. Agroecosys., 52, 213-223, 1998.

Howarth, R. W., Billen, G., Swaney, D., Townsend, A., Jaworski, N., Lajtha, K., Downing, J. A., Elmgren, R., Caraco, N., Jordan, T., Berendse, F., Freney, J., Kudeyarov, V., Murdoch, P., and Zhu, Z. L.: Regional nitrogen budgets and riverine N\&P fluxes for the drainages to the North Atlantic Ocean: Natural and human influences, Biogeochemistry, 35, 75-139, 1996.

Howarth, R. W., Sharpley, A., and Walker, D.: Sources of nutrient pollution to coastal waters in the United States: Implications for achieving coastal water quality goals, Estuaries, 25, 656-676, 2002.

Howarth, R. W., Swaney, D. P., Boyer, E. W., Marino, R., Jaworski, N., and Goodale, C.: The influence of climate on average ni- trogen export from large watersheds in the Northeastern United States, Biogeochemistry, 79, 163-186, 2006.

Hsu, S. C., Tsai, F. J., Lin, F. J., Chen, W. N., Shiah, F. K., Huang, J. C., Chan, C. Y., Chen, C. C., Liu, T. H., Chen, H. Y., Tseng, C. M., Hung, G. W., Huang, C. H., Lin, S. H., and Huang, Y. T.: A super Asian dust storm over the East and South China Seas: Disproportionate dust deposition, J. Geophys. Res.-Atmos., 118, 7169-7181, doi:10.1002/jgrd.50405, 2013.

Huang, J.-C., Lee, T.-Y., Kao, S.-J., Hsu, S.-C., Lin, H.-J., and Peng, T.-R.: Land use effect and hydrological control on nitrate yield in subtropical mountainous watersheds, Hydrol. Earth Syst. Sci., 16, 699-714, doi:10.5194/hess-16-699-2012, 2012.

Huang, J. C., Lee, T. Y., and Lee, J. Y.: Observed magnified runoff response to rainfall intensification under global warming, Environ. Res. Lett., 9, 034008, doi:10.1088/1748-9326/9/3/034008, 2014.

Hunter, H. M. and Walton, R. S.: Land-use effects on fluxes of suspended sediment, nitrogen and phosphorus from a river catchment of the Great Barrier Reef, Australia, J. Hydrol., 356, 131146, 2008.

Hutchison, J. S. and Henry, H. L.: Additive Effects of Warming and Increased Nitrogen Deposition in a Temperate Old Field: Plant Productivity and the Importance of Winter, Ecosystems, 13, 661672, 2010.

Jeuken, A., Veefkind, J. P., Dentener, F., Metzger, S., and Gonzalez, C. R.: Simulation of the aerosol optical depth over Europe for August 1997 and a comparison with observations, J. Geophys. Res.-Atmos., 106, 28295-28311, 2001.

Kaushal, S. S., Groffman, P. M., Band, L. E., Shields, C. A., Morgan, R. P., Palmer, M. A., Belt, K. T., Fisher, G. T., Swan, C. M., and Findlay, S. E. G.: Interaction between urbanization and climate variability amplifies watershed nitrate export in Maryland, Environ. Sci. Technol., 42, 5872-5878, 2008.

Lee, T.-Y., Shih, Y.-T., Huang, J.-C., Kao, S.-J., Shiah, F.-K., and Liu, K.-K.: Speciation and dynamics of dissolved inorganic nitrogen export in the Danshui River, Taiwan, Biogeosciences, 11, 5307-5321, doi:10.5194/bg-11-5307-2014, 2014.

Lelieveld, J. and Dentener, F. J.: What controls tropospheric ozone?, J. Geophys. Res.-Atmos., 105, 3531-3551, 2000.

Lin, T.-C., Shaner, P.-J. L., Wang, L.-J., Shih, Y.-T., Wang, C.P., Huang, G.-H., and Huang, J.-C.: Effects of mountain tea plantations on nutrient cycling at upstream watersheds, Hydrol. Earth Syst. Sci., 19, 4493-4504, doi:10.5194/hess-19-44932015, 2015.

Liu, J., You, L., Amini, M., Obersteiner, M., Herrero, M., Zehnder, A. J. B., and Yangd, H.: A high-resolution assessment on global nitrogen flows in cropland, P. Natl. Acad. Sci. USA, 107, 80358040, 2010.

Liu, S. C., Fu, C. B., Shiu, C. J., Chen, J. P., and Wu, F. T.: Temperature dependence of global precipitation extremes, Geophys. Res. Lett., 36, L17702, doi:10.1029/2009GL040218, 2009.

McCrackin, M. L., Harrison, J. A., and Compton, J. E.: Factors influencing export of dissolved inorganic nitrogen by major rivers: A new, seasonal, spatially explicit, global model, Global Biogeochem. Cy., 28, 269-285, doi:10.1002/2013GB004723, 2014.

McIsaac, G. F., David, M. B., Gertner, G. Z., and Goolsby, D. A.: Relating Net Nitrogen Input in the Mississippi River Basin to Nitrate Flux in the Lower Mississippi River: A Comparison of Approaches, J. Environ. Qual., 31, 1610-1622, 2002. 
Ohara, T., Akimoto, H., Kurokawa, J., Horii, N., Yamaji, K., Yan, X., and Hayasaka, T.: An Asian emission inventory of anthropogenic emission sources for the period 1980-2020, Atmos. Chem. Phys., 7, 4419-4444, doi:10.5194/acp-7-4419-2007, 2007.

Peng, T. R., Lin, H. J., Wang, C. H., Liu, T. S., and Kao, S. J.: Pollution and variation of stream nitrate in a protected high-mountain watershed of Central Taiwan: evidence from nitrate concentration and nitrogen and oxygen isotope compositions, Environ. Monit. Assess., 184, 4985-4998, 2012.

Rockström, J., Steffen, W., Noone, K., Persson, A., Chapin, F. S., Lambin, E. F., Lenton, T. M., Scheffer, M., Folke, C., Schellnhuber, H. J., Nykvist, B., de Wit, C. A., Hughes, T., van der Leeuw, S., Rodhe, H., Sorlin, S., Snyder, P. K., Costanza, R., Svedin, U., Falkenmark, M., Karlberg, L., Corell, R. W., Fabry, V. J., Hansen, J., Walker, B., Liverman, D., Richardson, K., Crutzen, P., and Foley, J. A.: A safe operating space for humanity, Nature, 461, 472-475, 2009.

Seitzinger, S. P., Harrison, J. A., Dumont, E., Beusen, A. H. W., and Bouwman, A. F.: Sources and delivery of carbon, nitrogen, and phosphorus to the coastal zone: An overview of Global Nutrient Export from Watersheds (NEWS) models and their application, Global Biogeochem. Cy., 19, GB4S01, doi:10.1029/2005GB002606, 2005.

Smith, S. V., Swaney, D. P., Buddemeier, R. W., Scarsbrook, M. R., Weatherhead, M. A., Humborg, C., Eriksson, H., and Hannerz, F.: River nutrient loads and catchment size, Biogeochemistry, 75, 83-107, 2005.
Sullivan, B. W., Smith, W. K., Townsend, A. R., Nasto, M. K., Reed, S. C., Chazdon, R. L., and Cleveland, C. C.: Spatially robust estimates of biological nitrogen $(\mathrm{N})$ fixation imply substantial human alteration of the tropical $\mathrm{N}$ cycle, P. Natl. Acad. Sci. USA, 111, 8101-8106, 2014.

Townsend, A. R., Martinelli, L. A., and Howarth, R. W.: The global nitrogen cycle, biodiversity, and human health, in: Biodiversity change and human health, edited by: Sala, O. E. and Meyerson, L. A., Island Press, Washington DC, USA, 159-179, 2009.

Tu, J.: Combined impact of climate and land use changes on streamflow and water quality in eastern Massachusetts, USA, J. Hydrol., 379, 268-283, 2009.

Van Drecht, G., Bouwman, A. F., Harrison, J., and Knoop, J. M.: Global nitrogen and phosphate in urban wastewater for the period 1970 to 2050, Global Biogeochem. Cy., 23, GB-A03, doi:10.1029/2009GB003458, 2009.

Venohr, M., Donohue, I., Fogelberg, S., Arheimer, B., Irvine, K., and Behrendt, H.: Nitrogen retention in a river system and the effects of river morphology and lakes, Water Sci. Technol., 51, 19-29, 2005.

Vitousek, P. M., Aber, J. D., Howarth, R. W., Likens, G. E., Matson, P. A., Schindler, D. W., Schlesinger, W. H., and Tilman, D. G.: Human alternation of the global nitrogen cycle: sources and consequences, Ecol. Appl., 7, 737-750, 1997.

Yan, X., Akimoto, H., and Ohara, T.: Estimation of nitrous oxide, nitric oxide and ammonia emissions from croplands in East, Southeast and South Asia, Global Change Biol., 9, 1080-1096, 2003. 